
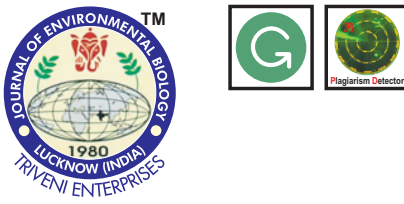

DOI : http://doi.org/10.22438/jeb/38/5(SI)/GM-11

\section{Journal of Environmental Biology}

ISSN: 0254-8704 (Print) ISSN: 2394-0379 (Online) CODEN: JEBIDP

\title{
Modeling the potential distribution of Anatolian black pine in the inner parts of Central Black Sea environment
}

Authors Info

S. Gülsoy ${ }^{1 *}$, Ö. Şentürk ${ }^{2}$ and i. Tümer $^{3}$

${ }^{1}$ Department of Forest Engineering, Faculty of Forestry, Süleyman Demirel University, Isparta, 32100, Turkey

${ }^{2}$ Department of Forestry, Mehmet Akif Ersoy University, Gölhisar, 15400, Turkey

${ }^{3}$ Amasya Forest Management Directorate, Aydınca Forest Enterprise, Amasya, 05200, Turkey

*Corresponding Author Email : serkangulsoy@sdu.edu.tr

Key words

Anatolian black pine,

Black Sea region,

Climatic factors,

Potential distribution

Publication Info

Paper received : 18.08 .2016

Revised received : 20.06.2017

Accepted : 28.06.2017

\begin{abstract}
Aim: Anatolian black pine (Pinus nigra Arnold), an economically important conifer, is widely distributed in Turkey. The main objective of the present study was to analyze the relationship between potential geographical distribution of this plant and some primary environmental factors in inner parts of Central Black Sea region of Turkey.
\end{abstract}

Methodology: Generalized Additive Model (GAM) technique was used to model the potential distribution of the Anatolian black pine in relation to environmental variables. The potential distribution map of Anatolian black pine in the district was created using Arc GIS software by Environmental Systems Resource Institute, Arc Map 10.1.

Results: Results of GAM showed that elevation, climate and bedrock formations were the most influential factors on the potential distribution of Anatolian black pine in the district.

Interpretation: Elevation appears to be the most important factor for potential distribution of Anatolian black pine. It seems that climatic factors depend on the elevation. Bedrock formations are other important environmental factors that might influence distribution of species.

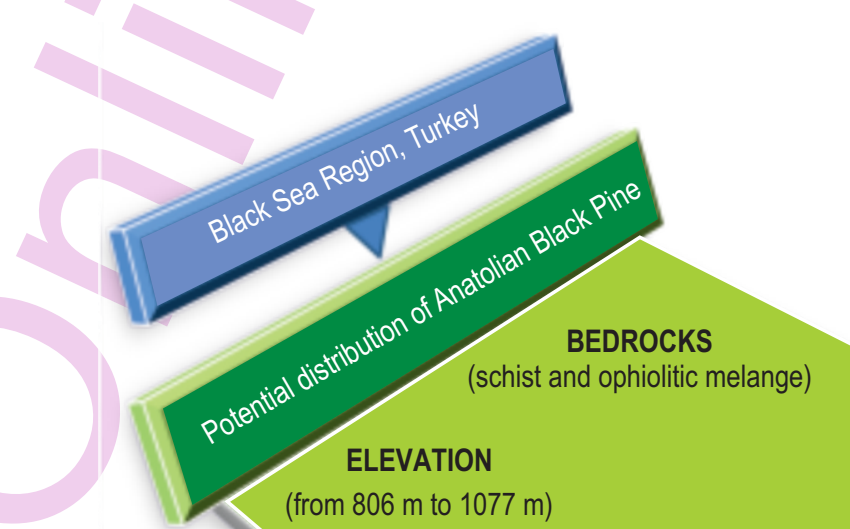

(from $806 \mathrm{~m}$ to $1077 \mathrm{~m}$ )

ASSOCIATIONS

elevation-climate

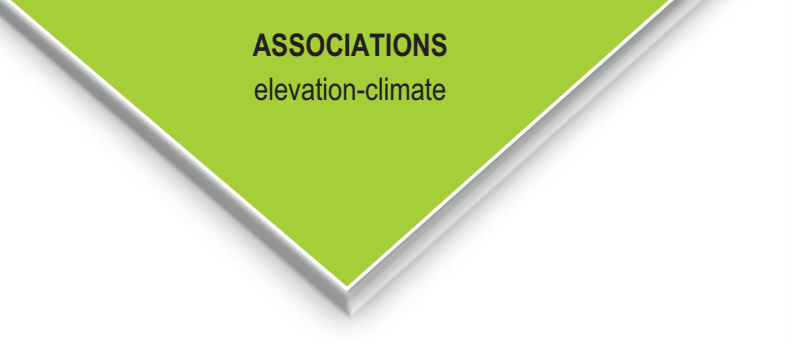




\section{Introduction}

On one hand, demand for forest products is increasing in parallel to the increased population density and technology, on the other hand the increased demand is leading to shrinkage of forest lands. Although this situation has not significantly influenced the developed countries, it is more evident in less developed and developing countries (Istanbullu, 1974).Statistical studies of the Food and Agriculture Organization (FAO, 2010) show that the total forest land across the world is shrinking by around 10 million hectares per year. The forest organizations of different countries try to preserve the existing forest lands and also strive to transform degraded forests into sustainaly productive forests. Every country endeavours to give priority to the management of forests using the main tree species that have widest geographical distribution.

Anatolian black pine (Pinus nigra Arnold) is one of the main forest tree species used extensively in the management of forests in Turkey (Ozkan and Gulsoy, 2009). This species is a typical southern Europe tree species that is distributed natively at between $5^{\circ}-40^{\circ}$ east longitudes extending from Morocco and Algeria in the west to Turkey in the east, and $35^{\circ}-48^{\circ}$ north latitudes extending from Morocco and Cyprus in the south to Austria and Crimea in the north (Critchfield and Little, 1966; Gaussen et al., 1993). In Turkey, Anatolian black pine is the most widely distributed taxon of black pine that has a number of varieties and ecotypes around the world (Alptekin, 1986; Ansin, 1994; Yaltirik, 1993).

Anatolian black pine covers an area of $4,693,060$ ha out of around 21.7 million hectares of total forest land in Turkey. While $2,580,193$ ha has normal canopy cover and $2,112,867$ ha has canopy closure with open space (GDF, 2012). This taxon is the third main forest tree species with respect to distribution area after Brutian pine and oak species, while it is the main forest tree species with respect to growing stock. Therefore, it is important to propagate this species in our forests through accurate methods and ensure that it contributes to the national economy and integrity of global ecosystem is sustained through forest management efforts. For this purpose, the best step will be to determine the potential geographical distribution of this species by management zones or regions, and put efforts to transform the degraded forests into productive forests. At the stage of transforming degraded forests into productive forests, it is critically important to determine and map the potential geographical distribution of the species (Atalay et al., 2014; Ozkan et al., 2015) and then integrate the maps with the management plans for afforesting right locations with right species.

Anatolian black pine, which has spread most extensively to the steppe regions in the inner parts of Turkey, has pure and mixed stands densely located at an altitude of 1200-2000 m along the Taurus Mountain Range in the Mediterranean Region (Atalay and Efe, 2012). Distributed over an area extending from lower elevations on the valleys facing the sea in the Western Anatolia to high elevations, this species is also distributed in the other parts of Northern Anatolia except the east part (Saatcioglu, 1959). The area located within boundaries of Aydınca Forest Division of Amasya Forest Department is one of the important distribution areas of this species which is distributed in moderately mountainous areas at an elevation of $400-1400$ m particularly in the inner parts of the Black Sea Region. The size of this area is $75,494.3$ ha, out of which $41,307.7$ ha is covered with forest while $34,186.6$ ha is non-forested. $8,088.6$ ha of the forested area is productive while $33,219.1$ ha is unproductive. $7,483.3$ ha of the forested land is covered by Anatolian black pine, out of which 4,424.7 ha is classified as partially degraded forest (FMP, 2011). In the present study an attempt was made to model and map potential geographical distribution of Anatolian black pine using GAM in the light of the above mentioned information.

\section{Materials and Methods}

Study area : Aydınca is located in the southeast of Amasya province between $40^{\circ} 45^{\prime}-40^{\circ} 21^{\prime} \mathrm{N}$ latitudes and $35^{\circ} 44^{\prime}-36^{\circ} 23^{\prime} \mathrm{E}$ longitudes on an area of $75,494.3$ ha (Fig. 1).

The area located in the transition zone extending from the inner parts of the Black Sea Region to the Central Anatolia is a young basin due to its geological and geomorphologic characteristics. There may be a drought in the period from July to November in the study area where the colder climate is dominant compared to the parts that are close to the coasts of Black Sea due to its location. According to the precipitation effectiveness index obtained according to the method of Thornthwaite (1948), the area is characterized by "arid-less fertile" climate (Senturk et al., 2014).

The bottom land in the inner parts of the area mainly has alluviums and sedimentary volcanic rocks while the mountainous parts are dominated by the formations of ophiolitic melange, schist and limestone rocks. Brown forest soil is the most common type of climatic soil that was formed due to the physical disintegration and chemical decomposition of these rocks in the course of time. The colour of the soils is darker and chestnut brown on more humid and sunny aspects where decomposition is better, while these soils usually have more organic content. On the other hand, areas where decomposition conditions are poor are covered with light coloured and reddish soils that have low humus content. Furthermore, flat terrains and bottom lands in the area as well as inner parts of valleys, are covered by also soils that are composed of alluvial and colluvial sediments due to gravity and the erosive and carrying capacity of rivers (FMP, 2011).

The area mainly has a rugged terrain and the highest point is Cami hill located at an elevation of $1956 \mathrm{~m}$ Yeşilırmakriver 

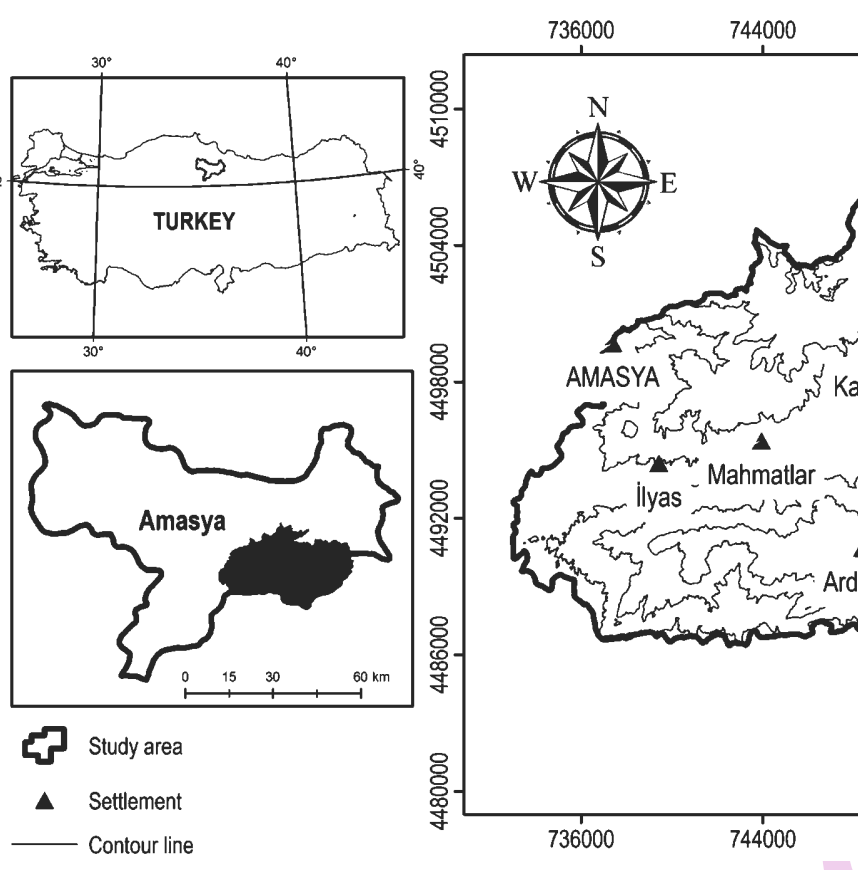

752000

760000

768000

776000

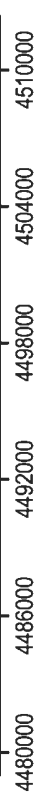

Fig. 1 : Site location map of the study site (Aydınca)

is the junction for many water courses in the form of streams and tributaries, which have important micro climatic effects on the organisms in the area. The area is located in the grid square of $A 6$ according to the grid system developed by Davis (1988) for Turkey. It has a rich flora while the most common plant families recorded in the area include Asteraceae, Lamiaceae, Fabaceae, Poaceae and Brassicaceae (Cansaran and Aydoğdu, 1998; Korkmaz, 2005). Furthermore, the most widely distributed tree species in forests include, respectively, oak species, black pine, juniper, brutian pine, oriental beech and scotch pine (Senturk et al., 2014).

Land surveys : Data were collected from 453 sampling plots within the boundaries of Aydınca. The size of each sampling plots was $400 \mathrm{~m}^{2}$. Presence-absence data of black pine were recorded for each sampling plot in order to model and map the potential geographical distribution of this species together with the environmental variables which were the response variable. Variables longitude, latitude and elevation were measured with the help of GPS in center of each sampling plot. Moreover, aspects were measured with compass and slope measurements were taken with a clinometer.

Digital maps including all variables that are subjected to statistical analysis are a necessary tool to model and map potential geographical distribution of a species (Mert et al. 2013). Therefore, a digital elevation model was created using contour maps same as with the land surveys. The slope, aspect and elevation at the coordinates of the sampling plots were obtained from the digital elevation model sand the field measurements were verified by digital maps. Data were also obtained from digital maps created in ArcMap 10.1 software using some index formulations. Aspect values of the sampling plots were converted to Radiation index values assuming that the use of aspect values directly in numerical calculations without any conversion with the help of an index may yield misleading results (McCune and Keon, 2002). Radiation index is calculated by the following formulation:

$$
\mathrm{RI}=\frac{[1-\cos ((\pi / 180)(\mathrm{Q}-30))]}{2}
$$

where refers to the angle of the aspect to the north. This formula gives values ranging from 0 to 1 . When the point with an angle of $202.5^{\circ}$ between the north and west is incorporated into the formula, the radiation index corresponds to "1", which shows the point with the longest sunshine duration depending on the aspect. In another word, this value is around " 0 " on the shaded aspects extending in north-northeast direction while it is around " 1 " on sunny aspects extending in a south-southeast direction.

In addition to the radiation index, heat and topographic position indices were the other two indirect variables included in the study considering that they might provide important results regarding the distribution of the species. The heat index is calculated by the following formula:

$\mathrm{HI}=\cos \left(\text { Radiant }\left((\text { Aspect)})-\text { Aspect }_{\max }\right)\right)^{*}(\tan ($ Radiant(Slope degree))))

which yields values ranging from -1 to 1 (Pal Axel et al., 2009). 
Contrary to the formulation of the radiation index, the angle of aspect and slope degree were also added the formulation of the

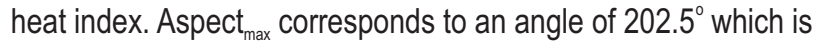
represented by "1" and shows the hottest points between the southern and western angles. On the other hand, if the value is closer to "- 1 ", it means that the area is located in a lowtemperature zone within the northern and eastern aspects.

Another variable included in the study was topographic position index, which shows values calculated using the elevations found in the digital elevation models. Positive values represent the hilly terrains and high mountainous areas, while 0 represents flat and near-flat plains, highlands and plateaus. Negative values represent a deep concave valley and hollow lands (Weiss, 2001).

Another variable obtained from digital maps was the slope position characteristics. The land form characteristics of the sampling plots, that included valley (1), lower slope (2), middle slope (3), upper slope (4) and ridge (5) were determined using the digital map and transferred to the data matrix (Tagil and Jenness, 2008).
The other variable evaluated in the study was the bedrock formations, which were determined through the digitalization of the maps obtained from the Directorate General for Mineral Research and Exploration and included in the environmental data matrix in the form of nominal data (Fig.2).

Considering that the climatic characteristic of the study site might be an important environmental variable for the distribution of the species, the bio-climate maps were downloaded from the database available on http://www.worldclim.org (Hijmans et al., 2005), based on which annual average temperature $\left({ }^{\circ} \mathrm{C}\right)$ and annual total average precipitation $(\mathrm{mm})$ were predicted. Table 1 shows all the 18 environmental variables and their abbreviations selected for the statistical analysis in order to model and map the potential distribution of the black pine in the area.

Statistical evaluation : For statistical evaluation, independent variables were subjected to Pearson Correlation Analysis, and the variables having high correlation and had representation capacity were selected at the modelling phase (Ozdamar, 2015).

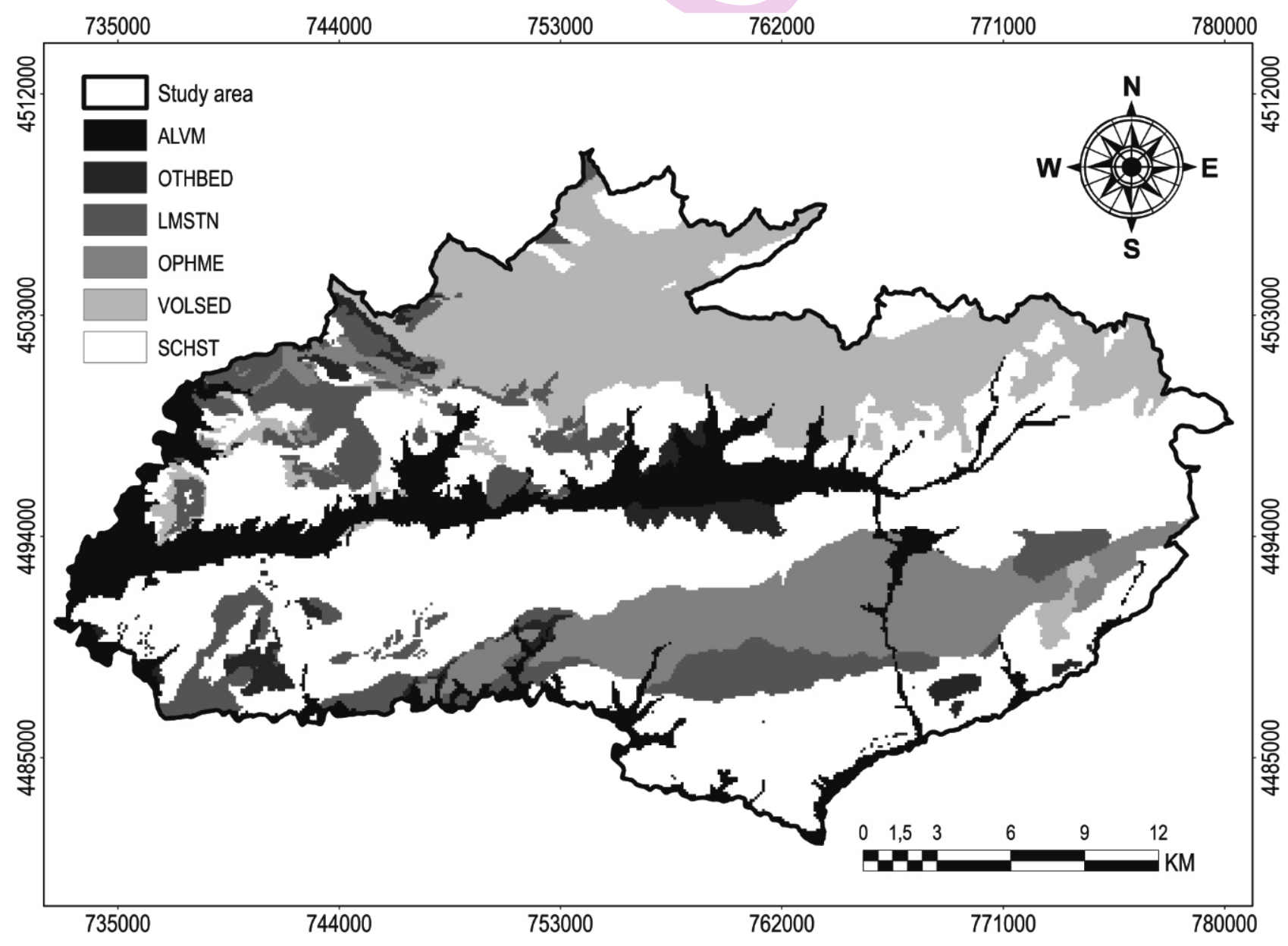

Fig. 2 : Existing bedrock formations in Aydınca 
Table 1 : Variables selected for modelling and mapping and the assigned codes

\begin{tabular}{llll}
\hline Variables & Codes & Variables & Codes \\
\hline Elevation $(\mathrm{m})$ & ELVTN & Schist & SCHST \\
Slope degree $\left({ }^{\circ}\right)$ & SLOPE & Sedimentary volcanic rock & VOLSED \\
Radiation index & RADIN & Ophiolitmelange & OPHME \\
Heatindex & HEATIN & Alluvium & ALVM \\
Topographic position index & TPIN & Limestone & LMSTN \\
Valley/Bottom slope position & VALLEY & Sandstone-mudstone & OTHBED \\
Lower slope position & LSLOPE & Pebble stone-Sandstone & \\
Middle slope position & MSLOPE & Serpantinite & \\
Upper slope position & USLOPE & Argillaceouslimestone & \\
Ridge position & RIDGE & Pebble stone & \\
Annual average temperature $\left({ }^{\circ} \mathrm{C}\right)$ & BIO1 & Marble & BLACKPINE \\
Annual average total precipitation $(\mathrm{mm})$ & BIO12 & Anatolian black pine & \\
\hline
\end{tabular}

Continuous variables to be evaluated at the modelling phase (elevation, slope, radiation index, temperature index and topographic position index)were subjected to Wilcoxon Rank Sum Test (Wilcoxon, 1945), while the nominal variables (bedrock and slope position)were subjected to Pearson chi-square test (López-López et al., 2007). Linear relations between the distribution of black pine and the environmental variables were thus identified. Generalized Additive Model (GAM) was used (Lehmann et al., 2002) for the modelling of the potential geographical distribution of the species. This is the modified version of Generalized Linear Model (GLM) (Moisen et al., 2006) and a non-parametrical method that models the response variable in a more flexible way using the total functions of independent variables in an additive way (Terziand Cengiz, 2009; KanKılıcandCavus, 2015). At the analysis phase, S-PLUS 6.1 software was used. The predictive values for each pixel in the digital maps were calculated using the variables in the model that was created using GAM. At the final phase of the study, regionalization of Anatolian black pine was applied in Aydınca districtand the potential geographical distribution map specific to Anatolian black pine was created using ArcMap 10.1software.

\section{Results and Discussion}

This study was conducted in Aydınca (Amasya) district to demarcate the potential geographical distribution of Anatolian black pine in the inner parts of the Black Sea Region of Turkey. Black pine was found in 111 out of 453 sampling plots in the district. Other important forest tree species found and recorded are various oak specices (Quercus spp.), brutian pine (Pinus brutia Ten.), Greek juniper (Juniperus excelsa M. Bieb.), oriental beech (Fagus orientalis Lipsky.) and scotch pine (Pinus sylvestris L.).

The annual average temperature was $10.2 \pm 0.7^{\circ} \mathrm{C}$, while the average annual total precipitation was $462.1 \pm 12.9 \mathrm{~mm}$ in the areas where black pine was distributed within the study site.
Table 2 presents results of Wilcoxon rank sum test applied at the next phase for the correlation between the environmental variables that contained continuous variables and the distribution of black pine. As regards the linear relations, statistically significant relations were found between ELVTN, RADIN and HEATIN as continuous variables. The elevation in the study site varied from 400 to $1800 \mathrm{~m}$. The black pine was found to occur at elevations from 650 to $1400 \mathrm{~m}$ and it was more widely distributed as the elevation increased. The average elevation of the areas where this species occurs was found to be $991.6 \pm 149.8 \mathrm{~m}$. The results of radiation index that was used in the study to represent aspect showed that the average radiation index was $0.5 \pm 0$.3in the distribution area of the species and $0.6 \pm 0.3$ in areas where it was not distributed. This indicates that this species may be distributed at shaded and sunny aspects but it may prefer the shaded aspects to some extent. The findings derived from the other variables used in the study, i.e., heat index and topographic position index, showed that the average temperature index value of the areas where black pine was distributed was $0.8 \pm 0.2$, while the topographic position index values varied from -22.6 to +18.1 .Assessment of the slope demonstrated that the species was distributed on a broad scale from flat terrains $\left(3^{\circ}\right)$ to very steep terrains $\left(30^{\circ}\right)$;the average land slope in the area was found to be $17.2^{\circ} \pm 5.8$.

Table 3 shows the results of Pearson Chi-Square test applied in the study in order to determine the linear relations between nominal independent variables i.e.,bedrock formation and slope position and the distribution of the species. The assessment of the bedrock formations revealed that black pine was dominantly distributed on schist $(47 \%)$ and ophiolitic melange (32\%) bedrocks. As regards the linear relations between the distribution of the species and the bedrock formations, statistically significant relations were found with OPHME, VOLSED and OTHBED, respectively. Finally, regarding the slope position that was also assessed in the study, a statistically significant relation was found only between MSLOPE and the distribution of black pine. 
Table 2 : Average values of continuous variables and linear relations with distribution of the species according to the results of Wilcoxon rank sum test

\begin{tabular}{|c|c|c|c|c|c|c|c|}
\hline \multirow[t]{2}{*}{ Variables } & \multicolumn{2}{|c|}{ Black pine (present) } & \multicolumn{2}{|c|}{ Black pine (absent) } & \multirow[t]{2}{*}{$w$} & \multirow[t]{2}{*}{$Z$} & \multirow[t]{2}{*}{$P$} \\
\hline & Average & Std. Error & Average & Std. Error & & & \\
\hline ELVTN & 991.6 & 149.8 & 924.9 & 272.0 & 73148.5 & -3.74 & 0.000 \\
\hline SLOPE & 17.2 & 5.8 & 17.6 & 6.4 & 24676 & -0.43 & 0.663 \\
\hline RADIN & 0.5 & 0.3 & 0.6 & 0.3 & 21907 & -2.74 & 0.006 \\
\hline HEATIN & 0.8 & 0.2 & 0.8 & 0.2 & 22640 & -2.13 & 0.032 \\
\hline TPIN & 0.7 & 8.1 & -0.3 & 8.5 & 76015 & -1.35 & 0.176 \\
\hline
\end{tabular}

Table 3 : Results of Pearson Chi-square test applied to determine the linear relations between nominal independent variables and distribution of black pine

\begin{tabular}{llllllll}
\hline Variable & & A & B & C & D & Chi-square & p \\
\hline Bedrock & SCHST & 173 & 169 & 58 & 53 & 0.093 & 0.760 \\
& VOLSED & 263 & 79 & 98 & 13 & 6.715 & 0.010 \\
& LMSTN & 300 & 42 & 103 & 8 & 2.197 & 0.138 \\
& OPHME & 323 & 19 & 76 & 35 & 53.855 & 0.000 \\
& ALVM & 337 & 5 & 111 & 0 & 1.641 & 0.200 \\
& OTHBED & 314 & 28 & 109 & 2 & 5.525 & 0.019 \\
\multirow{5}{*}{ Slope position } & VALLEY & 190 & 152 & 72 & 39 & 2.978 & 0.084 \\
& LSLOPE & 334 & 8 & 108 & 3 & 0.047 & 0.829 \\
& MSLOPE & 327 & 15 & 99 & 12 & 6.172 & 0.013 \\
& USLOPE & 334 & 8 & 107 & 4 & 0.520 & 0.471 \\
& RIDGE & 183 & 159 & 58 & 53 & 0.053 & 0.818 \\
\hline
\end{tabular}

Cross - Validation

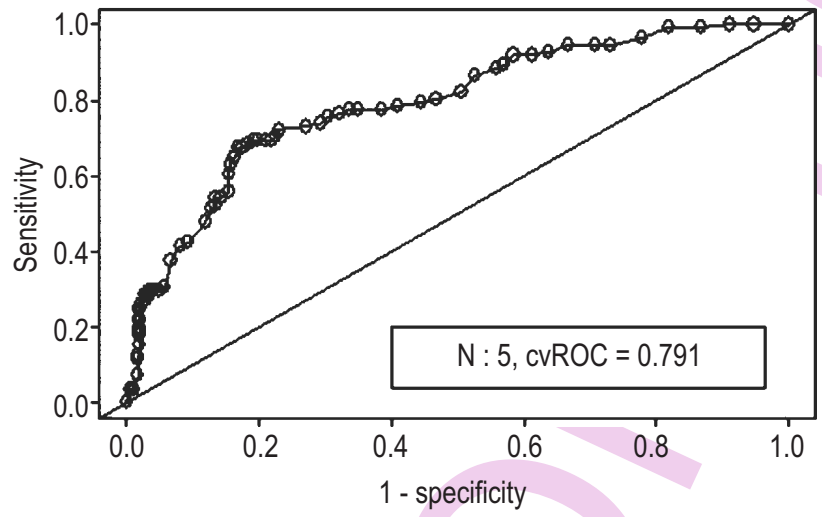

Fig. 3 : Coefficients of validation and cross validation of the model

The results of Pearson Correlation Analysis applied for the independent variables indicate high correlation between elevation and average annual temperature ( $r:-0.971 ; p: 0.000)$ and average annual total precipitation ( $r: 0.908 ; \mathrm{p}: 0.000)$. Therefore, elevation was selected as the representative because it was aimed to eliminating the bias during the modelling phase.

The measured values of the environmental variables that were predicted to have an effect on the potential distribution of the

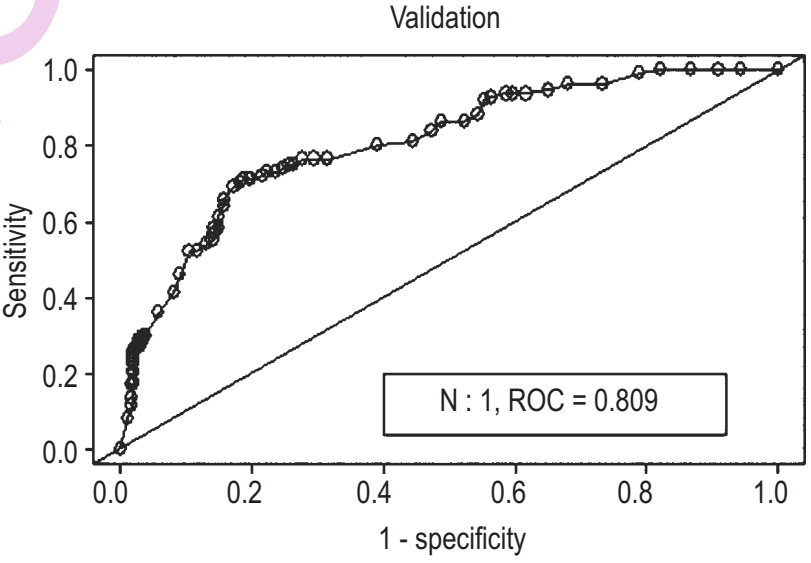

species and the presence-absence data of black pine in the sampling plots were modelled using GAM technique. During the modelling phase, Quasi model ANOVA (F test) option with a degree of freedom (d.f.) of 4 was used. As a result of GAM; independent variables, such as, did slope, radiation index, temperature index, topographic position index and slope position not appear in the model because they were not significant. Elevations and bedrock formations were predominant and variables in the potential distribution model (PDM) with the best 


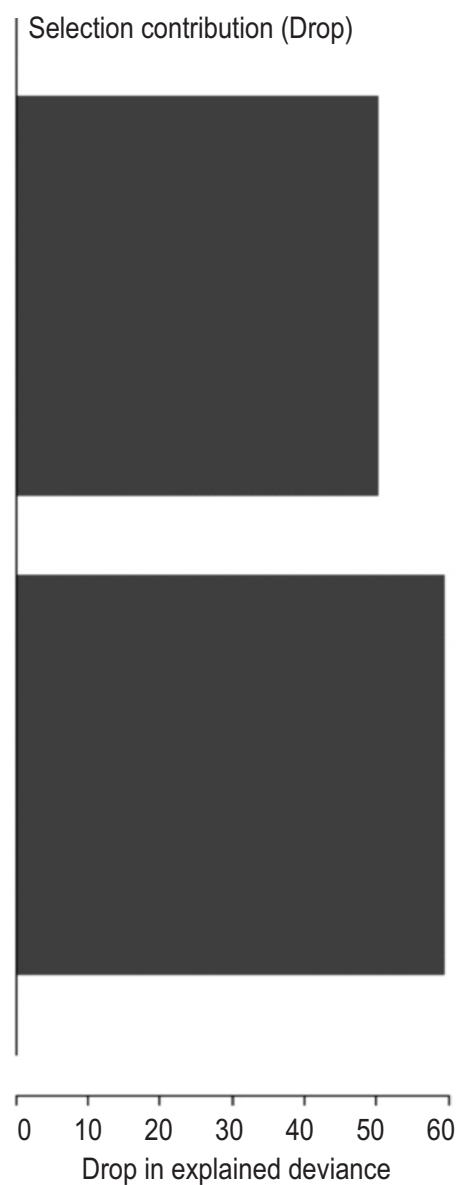

Fig. 4 : Share of variables in the model

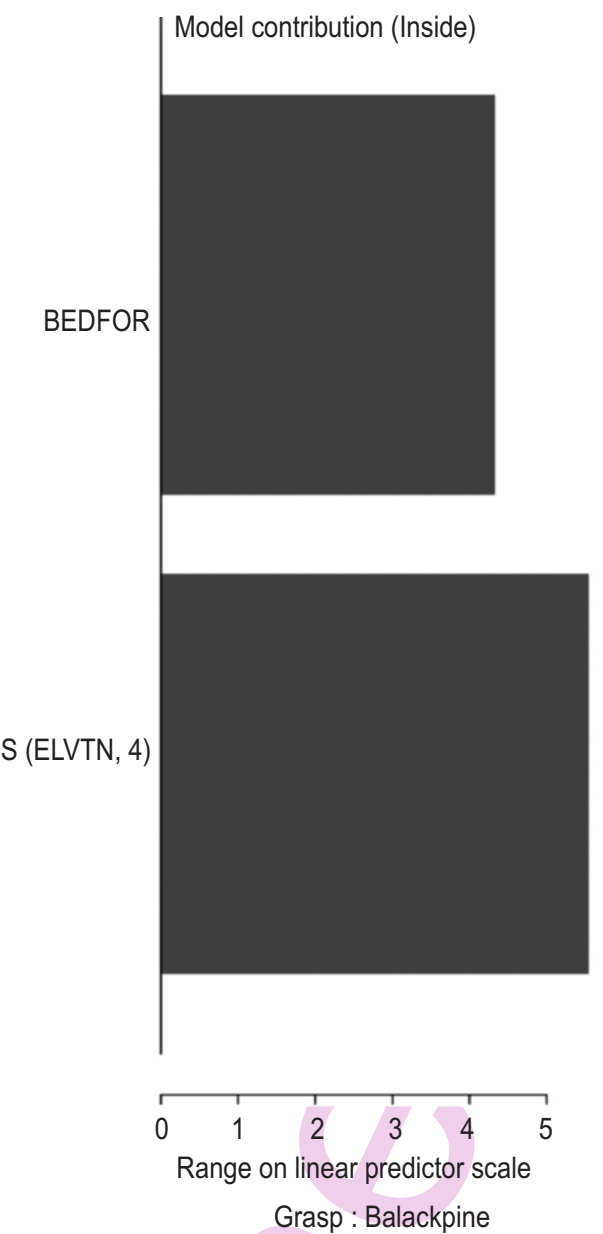

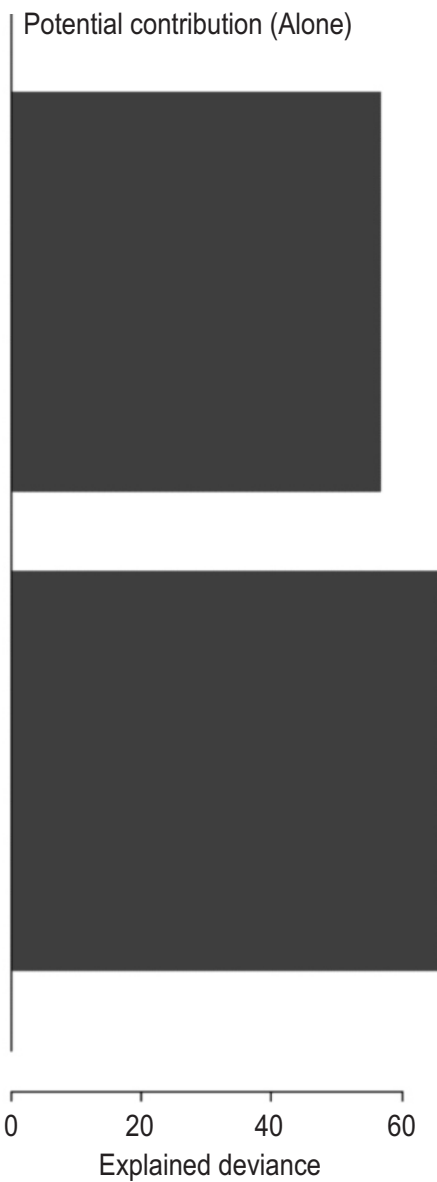

result according to the gradual selection criteria. The best model that explained the potential geographical distribution of the species in the area is shown below.

\section{$\operatorname{PDM}($ BLACKPINE $)=s($ ELVTN, 4$)+$ BEDFOR}

In this formulation, s curve represents spline smoothing factor, while 4 is the degree of freedom (d.f.). The validation results of the model are shown in Fig. 3.

According to the graph, the ROC (Receiver Operating Characteristics) value was 0,809 , the cvROC value was 0.791 . The share of elevation and bedrock formation was around $58 \%$ and $42 \%$, respectively (Fig. 4), when a reduction from the main model was made. Similarly, the share of these variables alone in the model for the potential distribution of the species was $63 \%$ for elevation, and $43 \%$ for bedrock formation. It shows that, elevation had a higher contribution than bedrock formation in the potential distribution of black pine.

The interpretation of the partial contribution of these two variables in the potential distribution model to the distribution of the species are presented as graphs (Fig.5).
As the graphs demonstrate, there is a significant positive correlation between elevation and potential distribution of the species. However, the descriptive line in the column chart (straight line) overlaps the reference line (dashed line) at the elevation from $806 \mathrm{~m}$ to $1077 \mathrm{~m}$. Therefore, it can be suggested that this elevation range is the most appropriate zone for the potential distribution of this species. Among the bedrock formations, this species seems to be predominantly distributed on schist and ophiolitic melange bedrocks. However, since the only bedrock formation where the descriptive line overlaps the reference line is the ophiolitic melange, it is concluded that this bedrock formation is more common in the potential distribution areas of this species. The model derived from GAMwas visualized through ArcMap 10.1software and the potential geographical distribution map was created for black pine in Aydınca district (Fig.6).

The Generalized Additive Model revealed that elevation and bedrock formation play an important role in the potential geographical distribution of the species in this region. The ROC value of the model determined by these variables was found to be 0.809. According to the classification proposed by Araújo et al., 

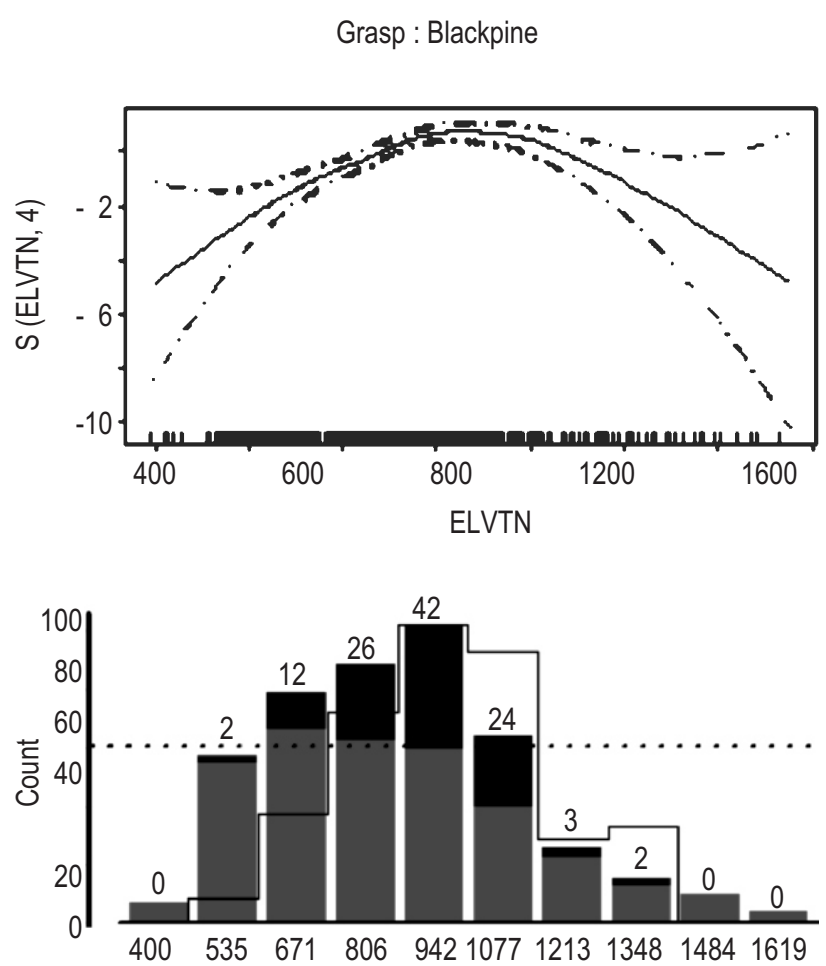

ELVTN
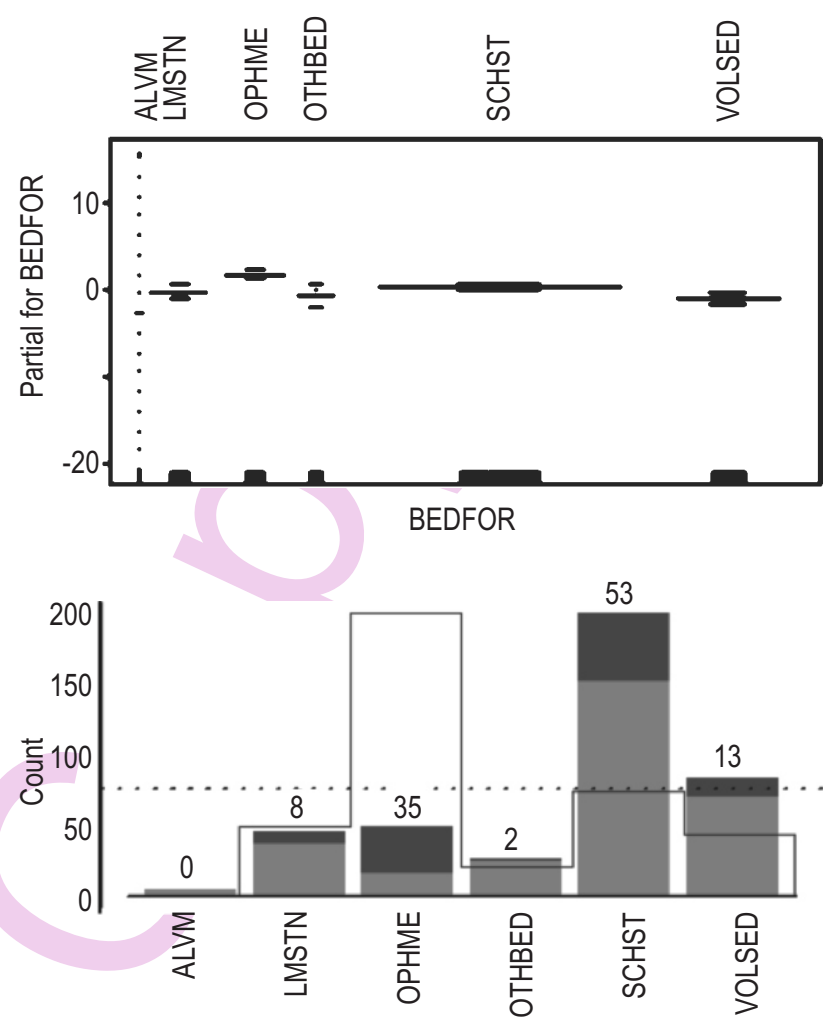

BEDFOR

Fig. 5 : Graphs showing the partial contribution of explanatory variables in the model

(2005) to show the quality of a model based on ROC values, a model with ROC value lower than 0.60 was unsuccessful, with $\mathrm{ROC}$ value ranging from 0.60 to 0.70 is poor, with $R O C$ value from 0.70 to 0.80 is appropriate, with ROC value from 0.80 to 0.90 is good, and a model with a ROC value greater than 0.90 is excellent. Therefore, the model created as a result of this study is a good model with a ROC value of 0.809 . Moreover, the crossvalidation tests validated the model with a cvROC value of 0.791 which was another important assessment criterion, is further indication of the explanatory power of the model (Ozkan, 2012).

It was observed that the black pine was distributed in the region at elevations ranging from $500 \mathrm{~m}$ to $1400 \mathrm{~m}$. It was reported that black pine can be seen from the sea level to $2000 \mathrm{~m}$ in the mountainous areas of the Middle Black region (Atalay and Efe, 2012).However,the results of this study showed that the most suitable potential distribution zone for black pine within that elevation range was from $800 \mathrm{~m}$ to $1100 \mathrm{~m}$ in the region. On the basis of these findings, it is concluded that the potential geographical distribution of the species in the region depending on elevation was actually associated with the climatic requirements. As a matter of fact, elevation in the region was highly correlated with average annual temperature ( $\mathrm{r}:-0.971$; p:0.000) and average annual total precipitation ( $r: 0.908 ; p: 0.000$ ). Continental climate gets more dominant in the inner parts of the
Black Sea Region due to the increased elevation from the sea level. While oak forests are more dominant at lower elevations in these parts, black pine and scotch pine are more dominant at higher elevations (Bahadir and Emet, 2010; Gunal, 2013). This suggests that requirements of precipitation and some degree of humidity of black pine are met in the region and depend on elevation. Increase in, precipitation due to increased elevation, starting from $800 \mathrm{~m}$, supports ecological conditions required by black pine, which persist upto $1100 \mathrm{~m}$. In this elevation range, another climate parameter that has an effect on the potential geographical distribution of the species is temperature. Atalay and Efe (2012) stated that the habitat conditions suitable for black pine were areas where the average annual temperature was 6-12 ${ }^{\circ} \mathrm{C}$ and average annual precipitation was $400-1000 \mathrm{~mm}$. The climatic characteristics of the elevation range where the species had the potential geographical distribution in the region are consistent with these values. Nevertheless, due to decrease in temperature at elevations higher than $1100 \mathrm{~m}$, black pine is gradually replaced by other species that have better tolerance to lower temperatures. It was observed that scotch pine especially was more dominant at higher elevations in the region. On the other hand, the findings obtained from the radiation and temperature indices used to investigate their linear relations with the distribution of black pine, supported the findings related to the elevation-climate associations (Atalay and Efe, 2012). 


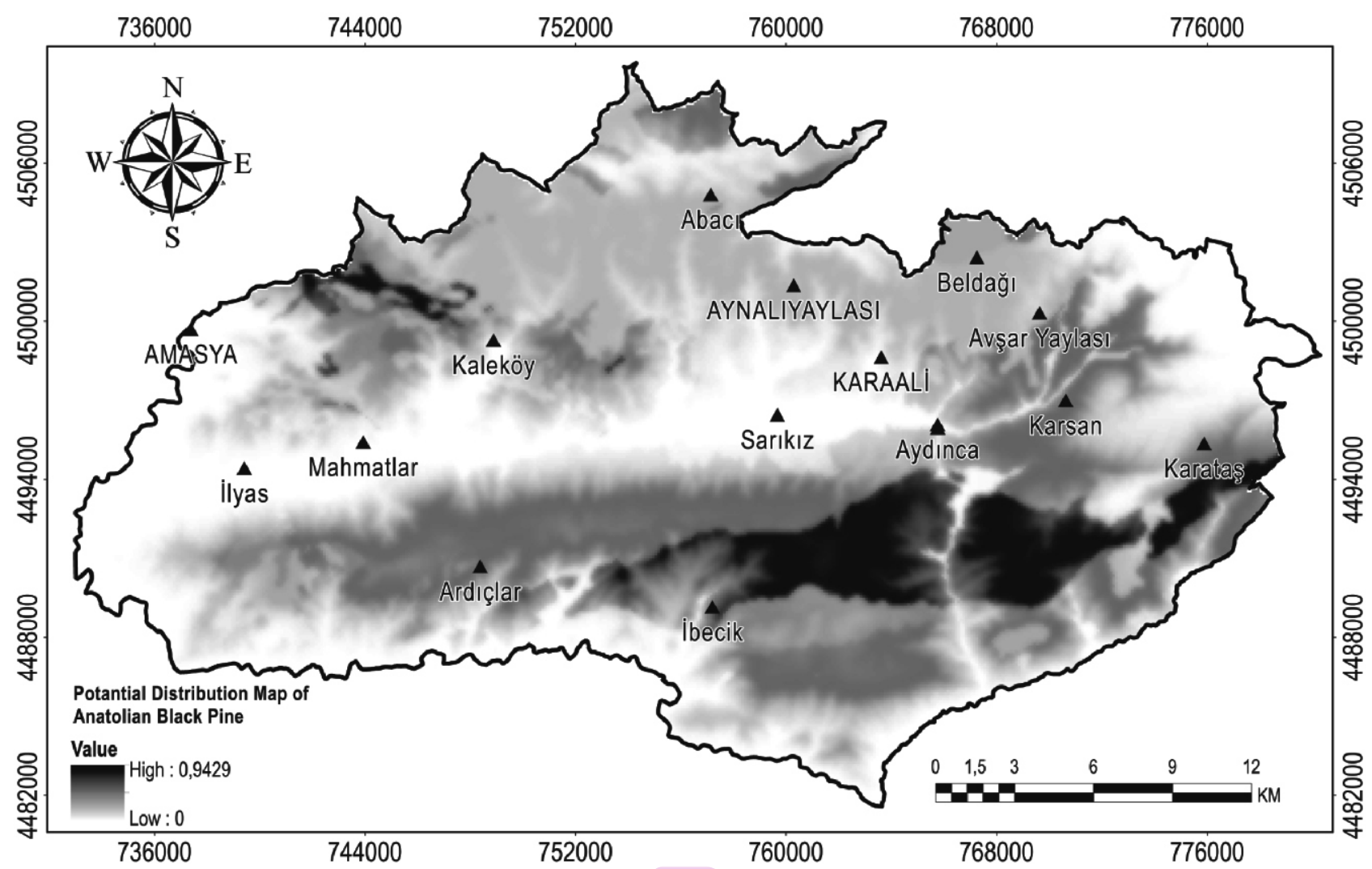

Fig. 6 : Map showing the potential geographical distribution of black pine in Aydınca (Amasya)

Bedrock formation is another important environmental factor that affects potential geographical distribution of plants in the region. Those sites in the region that had ophiolitic melange bedrock formation were more suitable for the potential geographical distribution of black pine. Ophiolitic melange is a metamorphic rock that was formed as a consequence of the contact of the rocks erupting from the ocean floor with sea-water. These rocks are usually covered by shallow, clay-type, heavy textured basic soils with high skeletal content (Yuksel, 2003). Black pine apparently has developed a potential ecological tolerance to these habitat conditions that do not seem to suitable appropriate for many plant species by converting its strong taproot to heart root to adapt to the shallow conditions of the environment. As a matter of fact, black pine was found in 111 sampling plots and $85 \%$ of these plots had moderately deep and shallow soils less than $75 \mathrm{~cm}$. On the other hand, $74 \%$ of 54 sampling plots found to have opihiolitic melange in the region are covered by moderately deep and shallow soils, up to $75 \mathrm{~cm}$ deep. However, it can not be stated fore sure that shallow soils on top of the ophiolitic melange bedrock represent deal habitat for black pine. On the other hand, it was stated that all types of bedrock formation can be suitable for the black pine distribution, but deep weathered parent materials are the best for growing condition of black pine (Atalay and Efe, 2012).Thus, It is very important to conduct further studies on the association between productivity of the species and environmental factors in the region.
As the map in Fig. 6 demonstrates, the primary potential geographical distribution areas of the species within the elevation range indicated in the model, are the northeast part of Ibecik dominated by ophiolitic melange and southeast part of Karataş. An area located in the northwest of Kaleköy and an area located between İlyas village, Ardıçlar and İbecikare the secondary potential distribution areas for black pine that is partially distributed in these areas.

In conclusion, it may be suggested that afforestation efforts will be successful if priority is given to the areas dedicated for black pine in this region. However, it would not be correct to generalize the findings obtained for this species in this region and to applyto the entire country because of considerable variation in the land forms (relief), soil and climatic characteristics in Turkey. There is a need for further studies on the ecology of this species in other areas under local conditions.

\section{Acknowledgment}

We acknowledge Scientific Research Projects Foundation (BAP-3548-YL1-13) at Suleyman Demirel University.

\section{References}

Alptekin, U.:Variabilitegeographique de Pinusnigra ssp. pallasiana L. Holmboe. J. Fac. Forestry Istanbul U., 36, 132-154 (1986). 
Ansin, R.: Tohumlu Bitkiler, Gymnospermae (AçıkTohumlular), I., [In Turkish].K.T.Ü. Publication of Forest Faculty, 122/15, Turkey (1994).

Araújo, M.B., R.G. Pearson, W. Thuiller and M. Erhard: Validation of species-climate impact models under climate change. Global Change Biol., 11, 1504-1513 (2005).

Atalay, I.: Vegetation geography of Turkey. Aegean Univ., Press (1994).

Atalay, I. and R. Efe: Ecological attributes and distribution of Anatolian black pine [Pinus nigra Arnold. subsp. pallasiana Lamb. Holmboe] in Turkey. J. Environ. Biol., 33, 509-519 (2012).

Atalay, I., R. Efe and M. Öztürk: Ecology and classification of forests in Turkey. Procedia- Social Behav. Sci., 120, 788-805, (2014).

Bahadir, M. and K. Emet: The analyse of essential tree species which present main climate types in Turkey, by using GIS. TUBAV J. Sci., 3, 94-105 (2010).

Cansaran, A. and M. Aydogdu: Flora of the area between Amasya Castle and the villages of Vermis and Yuvacık. Turk. J. Bot., 22, 269-283 (1998).

Critchfield, W.B. and E.L. Little: Geographic distribution of the pines of the world. U.S.D.A. Forest Service, Miscellaneous Publications, Washington DC, 991, 97 (1966).

Davis, P.H.: Flora of Turkey and The East Aegean Islands. Edinburgh Univ. Press.,Vol. 1-9, Edinburgh (1988).

FAO: Global Forest Resources Assessment 2010. Food and Agriculture Organization of The United Nations, Roma, Italy, p. 378 (2010).

FMP (Forest Management and Planning): Aydınca Ormanişletme Şefliği 2011-2030 Dönemine Ait Fonksiyonel Orman Amenajman Planı [In Turkish]. Amasya Forest Management Directorate, p. 410 (2011).

Gaussen, H., V.H. Heywood and A.O. Chater: Pinus L. In: Flora Europaea. Psilotaceaeto Platanaceae (Eds.: T.G. Tutin, N.A. Burges, A.O. Chater, J.R. Edmondson, V.H. Heywood, D.M. Moore, D.H. Valentine, S.M. Walters and D.A. Webb). Vol. 1, Cambridge, UK: Cambridge University Press (1993).

GDF (General Directorate of Forestry): Türkiye Orman Varlığı-2012 [In Turkish]. Republic of Turkey, Ministry of Forestry and Water Affairs, General Directorate of Forestry, Forest Management and Planning Department, Publication No.: 85, Inventory No.: 12, Kırış, R. (Edt.), p. 27 (2012).

Gunal, N.: The effects of the climate on the natural vegetation in Turkey. Online Thematic J. Turk. Stud., 5, 1-22 (2013).

Hijmans, R.J., S.E. Cameron, J.L. Parra, P.G. Jones and A. Jarvis: Very high resolution interpolated climate surfaces for global land areas. Int. J. Climatol., 25, 1965-1978 (2005).

Istanbullu, T.: Türkiye' deormanişletmeciliğininseyriiçindeyerliveyabancı girişimlervebugünküdurumu [In Turkish]. J. Fac. Istanbul U., 24, 119-123 (1974).

KanKılıc, B. and M. Cavus: Flexible logistic models with correlated variables. Turkiye Klinikleri J. Biostat., 7, 90-95 (2015).

Korkmaz, H., E. Yalcin, A. Engin and C. Yildirim: Flora of Tavsan Mountain (Merzifon-Amasya). The Herb J. Syst. Bot., 12, 103-140 (2005).

Lehmann, A., J.M. Overton and J.R. Leathwick: GRASP: generalized regression analysis and spatial prediction. Ecol. Model., 157, 189-
207 (2002).

López-López, P., C. Garcíe-Ripollés, Á. Soutullo, L. Cadahía and V. Urios: Identifying potentially suitable nesting habitat for golden eagles applied to 'important bird areas' design. Anim. Conservat., 10, 208-218 (2007).

McCune, B. and D. Keon: Equations for potential annual direct incident radiation and heat load. J. Veget. Sci., 13, 603-606 (2002).

Mert, A., O. Şentürk, C.O. Guney, D. Akdemir and K. Ozkan: Mapping of some distal variables available for mapping habitat suitabilities of the species: A case study of Buldan district. GeoMed 2013 The 3rd International Geography Symposium, (Eds.: I. Atalay and R. Efe), KemerAntalya, p. 210 (2013).

Moisen, G.G., E.A. Freeman, J.A. Blackard, T.S. Frescino, N.E. Zimmermann and T.C. Edwards: Predicting tree species presence and basal area in Utah: a comparison of stochastic gradient boosting, generalized additive models, and tree-based methods. Ecol. Model., 199, 176-187 (2006).

Ozdamar, K.: PaketProgramlar İle İstatistikselVeriAnalizi-Cilt 1 [In Turkish]. 10. Edition, Nisan Book store, Eskişehir, p.419 (2015)

Ozkan, K.: Identification of driving factors for presence of endemic species in the Aglasun district of the Mediterranean Region, Turkey. Pol. J. Ecol., 60, 291-30 (2012).

Ozkan, K. and S. Gulsoy: Effect of environmental factors on the productivity of Crimean pine (Pinusnigra ssp. pallasiana) in Sutculer, Turkey. J. Environ. Biol., 30, 965-970 (2009).

Ozkan, K., O. Senturk, A. Mert and M.G. Negiz: Modeling and mapping potential distribution of Crimean juniper (Juniperus excelsa Bieb.) using correlative approaches. J. Environ. Biol.,36, 9-15(2015).

Pal Axel, O., M. Linda-Maria, and B. Hans Henrik: Acidification of sandy grass lands - consequences for plant diversity. App. Veget. Sci., 12, 350-361 (2009).

Saatcioglu, F.: Silvikültür Ders Notları (RotoBaskısı) [ln Turkish]. Istanbul, pp. 127-131 (1959).

Senturk, O., S. Gulsoy and I. Tumer: Relationship between distribution of Turkey Oak (Quercuscerris L.) and site factors in Aydınca district forests of Amasya, Turkey. MAKU FEBED, 5, 13-21 (2014).

Tagil, S. and J. Jenness: GIS-based auotmated land form classification and topographic, land cover and geologic attributes of landforms around the Yazoren Polje, Turkey. J. Appl. Sci., 8, 910-921 (2008).

Terzi, Y. and M.A. Cengiz: Using of generalized additive model for model selection in multiple linear regression. Sci. Res. Essays., 4, $867-$ 871 (2009).

Thornthwaite, C.W.: A new and improved classification of climates. Geogr. Rev., 38, 55-94 (1948).

Weiss, A.: Topographic position and landforms analysis: Poster presentation, ESRI User Conference, San Diego, CA(2001).

Wilcoxon, F.: Individual comparisons by ranking methods. Biometrics Bulletin, 1, 80-83 (1945).

Yaltitrik, F.: Dendroloji (Gymnospermae) Kitabı [In Turkish]./stanbul University Publications, No, 386, p. 320 (1993).

Yuksel, M.: Physical, chemical and mineralogical properties of soils formed on the Çankiri-Eldivanofiolit complex. J. Agricult. Fac. Gaziosmanpasa Uni., 20, 145-152 (2003). 